\title{
THE CASE OF THE DISAPPEARING DEFENDANT: AN ECONOMIC ANALYSIS
}

Imagine an injurer harms a victim. If the injurer is solvent and the victim can hale her into court, the victim may receive compensation for damages. If the injurer is insolvent, or it is too costly for the victim to bring an action against the injurer, then from the perspective of the victim, the injurer has disappeared-the victim will receive no compensation.

The effect of an injurer's potential disappearance on her incentive to take care to avoid accidents is more subtle. One might think that the more a potential injurer believes that future liability will be avoided, the less care she would take to avoid accidents. A close analysis, however, reveals that the amount of care an injurer will take depends critically on whether she faces a negligence or strict liability rule and what kind of scheme the courts devise for spreading the risk of the injurer's disappearance among other potential injurers. ${ }^{1}$

This Comment employs an economic analysis of the problem of the disappearing defendant. The analysis evaluates the relative efficiency $^{2}$ of a number of liability rules governing a variety of different types of accidents assuming that a potential injurer realizes that the victim may never recover damages. The analysis is useful in providing a framework for evaluating the courts's and commentators' ${ }^{34}$ attempts to

1 See infra note 18 and accompanying text.

2 One liability rule is relatively more efficient than another if it is Pareto-superior, i.e., under some circumstances it provides better incentives for potential tortfeasors to take efficient amounts of care, see infra note 18 and accompanying text, and it never provides worse incentives.

See, e.g., Moody v. Kirkpatrick, 234 F. Supp. 537 (M.D. Tenn. 1964); American Motorcycle Ass'n v. Superior Court, 20 Cal. 3d 578, 578 P.2d 899, 146 Cal. Rptr. 182 (1978); Judson v. Peoples Bank \& Trust Co., 25 N.J. 17, 134 A.2d 761 (1957); Aalco Mfg. Co. v. City of Espanola, 95 N.M. 66, 67, 618 P.2d 1230, 1231 (1980).

- Commentators' discussions are limited to cases involving multiple tortfeasors where one of the tortfeasors becomes insolvent or is absent. See Myse, The Problem of the Insolvent Contributor, 60 MARQ. L. REv. 891 (1977); Note, 12 RuTGERs L. REv. 533, 537-38 (1958) (discussing Judson v. Peoples Bank \& Trust Co., 25 N.J. 17, 134 A.2d 761 (1957)); see also UNIF. Contributions AMONG TorTfEasors AcT § 2 commissioner's comment, 12 U.L.A. 88 (1975) ("it is not only difficult but unwise to try to state an express rule dealing with all the equitable situations which may arise"); Restatement (SECOND) OF TORTS § 886A comment c (1979) ("when there are three tortfeasors and one of them is clearly insolvent or is beyond the jurisdiction, the amount of contribution fairly allowable between the other two may reasonably be affected and the court may be expected to do what is fair and equitable under the circumstances"); Rizzo \& Arnold, Causal Apportionment in the Law of Torts: An Economic Theory, 80 ColuM. L. REv. 1399, 1422 (1980). In comparative fault jurisdictions, see UNIF. 
grapple with the problem of the disappearing defendant and in highlighting a consideration that has not yet received a systematic treatment in the economics-of-law literature. ${ }^{\sigma}$ The Comment details some rather striking differences between a negligence and a strict liability rule, and concludes that the former is more efficient.

The reader should be cautious in interpreting the conclusions of the Comment. First, the analysis relies on a number of controversial assumptions, the validity of which may depend upon the nature of accidents and potential injurers. For example, it is assumed that a potential injurer decides how much care to take to avoid accidents depending upon the injurer's assessment of her likelihood of insolvency or absence from a lawsuit. Obviously that assumption is more likely to be accurate of corporate decisions on product and worker safety than of individuals' decisions on how much care to take when crossing the street. Second, although the analysis compares the relative efficiency of the negligence rule to that of the strict liability rule, it should not be interpreted as providing a comprehensive comparison of the effects and desirability of negligence and strict liability rules. Instead, the Comment focuses on the more narrow question of how alternative liability rules affect potential injurers' incentives to take care in the face of a likelihood of disappearance.

Part I of the Comment briefly describes the problem of the disappearing defendant and the legal rules used to allocate the risk of an injurer's insolvency or absence among the victim and other tortfeasors, if any. Part II presents an economic analysis of single defendant acci-

Comparative Fault AcT § 2(d), 12 U.L.A. 37 (Supp. 1983) ("the court . . shall reallocate any uncollectible amount among the other parties, including a claimant at fault, according to their respective percentages at fault"); Fleming, Report to the Joint Committee of the California Legislature on Tort Liability on the Problems Associated with American Motorcycle Association v. Superior Court, 30 Hastings L.J. 1465, 1491-94 (1979).

- See, e.g., R. Posner, Economic ANalysis of Law 119-61 (2d ed. 1977); Landes \& Posner, Joint and Multiple Tortfeasors: An Economic Analysis, 9 J. LeGaL STUD. 517 (1980); Shavell, Strict Liability Versus Negligence, 9 J. LEGal STUD. 1 (1980); Golding, Economic Efficiency of Liability Rules for Joint Torts with Uncertainty 2 (1982) (Federal Trade Comm'n Working Paper No. 67).

In a forthcoming article, Shavell, Liability for Harm Versus Regulation of Safety, 13 J. Legal STud. (forthcoming 1984), Shavell contends that where potential injurers might be incapable of paying for the full amount of harm that they cause or where potential injurers might not face the threat of suit for the harm they cause, it is preferable to regulate these injuries through the use of liability rules. This Comment complements Shavell's analysis by showing how negligence and strict liability rules fail to encourage efficient precautionary behavior. The analysis in the Comment, however, indicates that the choice of liability rules-strict liability versus negligence and recovery versus simple-affects the extent to which potentially insolvent or absent injurers will take inefficiently low levels of care. 
dents and concludes that a negligence rule induces more efficient behavior than a strict liability rule. Part III presents an economic analysis of accidents involving joint tortfeasors and argues that a negligence liability rule combined with a rule that places the risk of one tortfeasor's disappearance on the other joint tortfeasors and not on the victim is most efficient. Part IV suggests applications of the analysis to problems raised by the market share liability theory and by manufacturers' ability to file for reorganization in response to substantial potential tort liabilities. A Technical Appendix is included for those with formal training in economics.

\section{Ex Post AND Ex Ante Views of the Problem}

Judges and commentators have focused on how to allocate a "missing" tortfeasor's liabilities among the victim and other tortfeasors. ${ }^{6}$ That approach is explicitly ex post because it assumes that an accident has occurred and that a tortfeasor is missing. Discussions of the relative merits of distributing the risk of insolvency or absence are, therefore, limited to debates over the fairness of ensuring a victim's compensation for injuries versus the fairness of requiring an injurer to pay for more than that injurer would have had to pay but for another tortfeasor's insolvency or absence.

An ex ante view of the problem, on the other hand, enables us to ask how the liabilities of an insolvent or absent injurer should be apportioned to ensure that a potentially insolvent or absent injurer takes an appropriate amount of precaution to avoid accidents. This ex ante view thus permits us to focus attention on the deterrent effects of a variety of possible legal rules. The first section of this part presents the ex post view of the problem and summarizes the courts' solutions. The second section describes the ex ante view in more detail. ${ }^{2}$

\section{A. The Ex Post View}

If one injurer harms a victim, and the injurer "disappears" by the time of the victim's suit, the victim is not compensated. From the ex post perspective the law appears to have no way of helping victims avoid bearing the risk of an injurer's insolvency. When there are a number of injurers, however, and one disappears, there are alternative rules for providing compensation for the victim. This Comment will discuss two such rules: the "simple rule" and the "recovery rule."

- See supra notes 3-4.

7 See Landes \& Posner, supra note 5, at 520. 
Under the simple rule, each injurer pays only for the share of the damages she caused and the victim goes uncompensated for the portion of the damages attributable to the insolvent or absent injurer. ${ }^{8}$ In effect, the risk of an injurer's disappearance is on the victim, just as in the single injurer case. Under the recovery rule, each injurer pays for her share of damages plus a portion of the damages attributable to the insolvent or absent injurer. Thus, the risk of disappearance is placed on the other tortfeasors and the victim is fully compensated. ${ }^{9}$

An example illustrates the difference between those two rules. Suppose that three injurers, $A, B$, and $C$ harmed a victim $D$ and that $C$ went insolvent between the time of the victim's injury and the time of her suit against $A$ and $B$. Suppose also that a court found $A, B$, and $C$ equally liable for the victim's $\$ 100,000$ injury. Under the simple rule, the victim would partially recover and collect $\$ 66,666$ ( $A$ and $B$ would each pay $\$ 33,333$ ) while under the recovery rule the victim would fully recover ( $A$ and $B$ each pay $\$ 50,000$ ). This brief review indicates that if

8 Id. at 529.

-The "recovery rule" and the "simple rule" are terms this Comment will use to refer to the effect of joint tortfeasors being found "jointly and severally liable" or "individually liable," respectively. Joint and several liability is imposed if injurers act in concert to commit a tort, fail to perform a common duty, were in a respondeat superior relationship, or were independent actors engaged in separate negligent acts that concurred to produce a single, indivisible injury to the victim. See RESTATEMENT (SECOND) OF TORTS $\S \S 875-879$ (1979); F. HARPER \& F. James, The LAw OF TORTS 692-95 (1956); W. Prosser, The Law of Torts 314-17 (4th ed. 1971); Note, Recent Developments in Joint \& Several Liability, 24 SYRACuSE L. REv. 1319-25 (1973). If joint and several liability is imposed, an insolvent or absent injurer's liability must fall on a solvent defendant, because any of the solvent injurers may be held liable for all of the victim's damages. If joint and several liability is imposed and there is a right to contribution, the risk of an injurer's insolvency will either be borne by the injurer who was held fully liable and is seeking contribution from the other joint tortfeasors or will be shared among all the solvent tortfeasors. The general rule, following contribution in contract law, is that the risk of insolvency is spread among all the solvent tortfeasors and does not lie with the named tortfeasor. See, e.g., Tucker v. Nicholson, 12 Cal. 2d 427, 433-34, 84 P.2d 1045, 1049 (1938); Lormier v. Julius Knack Coal Co., 246 Mich. 214, 218-19, 224 N.W. 362, 364 (1929); Wilson v. Crutcher, 176 Okla. 481, 481, 56 P.2d 416, 417 (1936); Cranston v. Ingle, 123 Or. 280, 285, 261 P. 55, 57 (1927); Cranston v. Stanfield, 123 Or. 314, 325, 261 P. 52, 55 (1927); Maresh v. Jennings, 38 S.W.2d 406, 408 (Tex. Civ. App. 1931); Appleford v. Snake River Mining, Milling \& Smelting Co., 122 Wash. 11, 210 P. 26, 28 (1922).

Joint and several liability is not imposed if the multiple tortfeasors' independent activities concur to produce a divisible injury to the victim which is capable of apportionment. When the injury is found divisible, each injurer is held individually liable only for a share of the victim's damages equal to the extent to which she contributed to the victim's injuries. Restatement (SECOND) OF TORTS $\S 881$ (1979); W. Prosser, supra, § 52 . What constitutes a divisible or an indivisible injury, however, is unclear, although it appears that injuries produced by nuisances are often considered divisible. See F. HARPER \& F. JAMES, supra, at 706-09; W. PROSSER, supra, §§ 52, 94.

A discussion of contributory negligence and comparative fault is beyond the scope of this Comment. For such a discussion, see Landes \& Posner, supra note 5, at 537-39. 
only one injurer harms the victim, and that injurer disappears, the law places the risk of the injurer's disappearance on the victim. If more than one injurer harms the victim, the court may follow either liability rule. $^{10}$

\section{B. The Ex Ante View}

An ex ante perspective permits us to consider how the risk of a tortfeasor's disappearance should be distributed to provide the correct incentives for potential injurers to take the appropriate amount of care to avoid accidents. It relies heavily on two insights: first, injurers, be they individuals or firms, always have an expected likelihood of insolvency or absence, and second, those expected likelihoods may vary across different injurers and time. The importance of these observations will be made clear in parts II and III of the Comment.

Three main factors determine an injurer's likelihood of disappearance. First, and rather obviously, the more likely it is that she will go bankrupt, the more likely it is that she will not be held fully liable for the injuries she causes. The likelihood of an individual's or firm's bankruptcy depends on a variety of factors. For example, the overall state of the economy affects the likelihood of bankruptcy. During periods of growth in the economy, the likelihood of a business failure is lower than during periods of recession or depression. In addition, the degree to which a firm's managers operate the firm in an inefficient way affects the firm's ability to compete with other firms. The less efficient the firm, the greater the firm's likelihood of bankruptcy. Also, the degree to which a firm sells a number of different product lines affects its likelihood of insolvency. If a firm sells a number of different products and the demand for one of those products declines, the firm may stay solvent because it has other product lines. If, however, the firm sells only one product and demand falls for that product, the firm may go insolvent. ${ }^{11}$ Finally, other factors, such as a corporation's capitalization,

10 Courts and legislatures have, to a limited extent, adopted rules that may be viewed as attempts to ensure that victims will not go uncompensated because of an injurer's insolvency or absence. Such ex ante attempts include compulsory insurance and bond requirements, e.g., 40 PA. Cons. Stat. ANN. $§ 1009.104$ (Purdon 1983), as well as rules permitting a court to pierce the corporate veil when a corporation is significantly undercapitalized, see, e.g., Becker v. Interstate Properties, Inc., 569 F.2d 1203, 1209 (3d Gir. 1977) (developer liable for failure to use solvent or adequately insured subcontractor); Minton v. Cavaney, 56 Cal. 2d 576, 579, 364 P.2d 473, 475, 15 Cal. Rptr. 641, 643 (1961) ("The equitable owners of a corporation . . . are personally liable ... when they provide inadequate capitalization and actively participate in the conduct of corporate affairs.").

${ }^{11}$ See Williamson, The Modern Corporation: Origins, Evolution, Attributes, $19 \mathrm{~J}$. EcoN. Lrr. 1537, 1558 n.35 (1981). 
the riskiness of the corporation's business strategy, and the burdens of government regulation may also play a role.

Second, court procedural rules affect the likelihood that an injurer may have to appear in court some day. The more expensive it is for a victim to bring a suit against an injurer, the higher the injurer's likelihood of absence. For example, to the extent that venue rules permit removal of a case to an injurer's home state and away from the victim's home state, the victim is inconvenienced and may be less likely to bring a suit, or more likely to settle for a smaller amount than she would otherwise. Service of process restrictions may also discourage suits.

Third, the type of injury the injurer inflicts on the victim affects the injurer's likelihood of disappearance. The longer the period between when the tort occurs and the time the victim discovers the injury, the greater the injurer's likelihood of insolvency or absence. For example, assuming that the injurer has a given annual likelihood of insolvency, if the injurer exposes the victim to a chemical that gives the victim cancer fifteen years later, the injurer will have a higher likelihood of insolvency at the time of the suit than if the chemical caused cancer one year after exposure.

The factors affecting injurers' expected likelihood of insolvency or absence indicate the ex ante perspective's second important insight: potential injurers face different likelihoods of insolvency or absence over time, and, at any given time, some injurer's may have greater likelihoods of insolvency than others. That observation implies that at any given time there is a distribution of injurers, some of whom have relatively large likelihoods of insolvency or absence and some of whom have relatively small likelihoods, and that that distribution may change over time.

The next two parts of the Comment present an economic analysis of the problem of the insolvent or absent injurers. Part II analyzes single injurer accidents and shows that the choice of a negligence or strict liability rule affects potential injurers' willingness to take care to avoid injuring potential victims. It concludes that a negligence rule is relatively more efficient. Part III examines multiple injurer accidents and analyzes the relative efficiency of the recovery and simple rules. That part concludes that the recovery rule is relatively more efficient than the simple rule.

\section{Single Injurer Accidents}

Imagine that in all accidents, one injurer harms one victim, and the victim is passive, that is, the amount of care the victim takes to avoid the accident does not affect the likelihood or severity of the vic- 
tim's injury. This admittedly highly stylized case is studied for two reasons. First, it may be descriptive of many types of accidents: for example, a water main bursts and floods the basement of a home; a plane crashes into a house; or a surgeon performs the wrong procedure on an anaesthetized patient. ${ }^{12}$ Second, this case is useful for introducing concepts that will be used to evaluate the relative efficiency of the recovery and simple rules in part III.

Section A briefly describes the traditional economic analysis of how much care injurers take to avoid accidents and how many accidents are likely to occur. In Section B, the traditional economic analysis is modified to incorporate the fact that injurers' expected likelihoods of insolvency or absence affect their decisions about how much care to take.

\section{A. Traditional Economic Analysis}

\section{Assumptions}

A traditional economic analysis of negligence and strict liability rules in the single injurer, passive victim case starts with a number of assumptions, some of them controversial. ${ }^{13}$ Since this Comment attempts to build on that analysis, only brief descriptions of those assumptions, which have been amply discussed in the literature, ${ }^{14}$ will be given.

The first assumption is that injurers are risk neutral. ${ }^{18}$ The second assumption is that the cost to potential injurers of avoiding accidents (the injurers" "care" costs) increases with the level of care they take, and an additional unit of care is more expensive at a high level of care

12 Shavell, supra note 5.

13 See, e.g., Brown, Toward an Economic Theory of Liability, 2 J. Legal STud. 323 (1973); Diamond, Accident Law and Resource Allocation, 5 BeLL J. EcoN. 366 (1974); Diamond, Single Activity Accidents, 3 J. LEgal STud. 107 (1974); Posner, A Theory of Negligence, 2 J. LeGal STUD. 39 (1972); Shavell, supra note 5.

14 See supra note 13.

15 If an injurer is risk neutral, that means that she would not prefer a certain $\$ 50$ over a 50-50 chance of winning $\$ 0$ or $\$ 100$. The assumption is somewhat controversial, as there may be some reason to think that injurers are risk averse, i.e., they would prefer the certainty of collecting $\$ 40$ to the $50-50$ chance of winning $\$ 100$ or $\$ 0$. See $R$. Luce \& H. RaIfFa, Games and Decisions 12-38 (1957).

The conclusions of this analysis do not change, however, if one assumes that injurers are risk averse. Risk aversion would imply that injurers would be more reluctant to "bet" on their future insolvency, and therefore, all else equal, would take greater care than was assumed in the analysis. Similarly, injurer risk aversion would increase an injurer's critical likelihood of insolvency or absence, see infra notes 31-34 and accompanying text, because she would be more reluctant to take less care and risk future accidents. 
that at a low level. That is, there are increasing total and marginal costs of accident avoidance. ${ }^{16}$ The third assumption is that injurers' accident liabilities (the injurers' "expected accident costs") decrease as injurers take more care, and an additional unit of care at a low level of care reduces expected accident costs by more than an additional unit at a high level of care. ${ }^{17}$ In other words, there are decreasing total and marginal expected accident costs.

The fourth assumption is that the legal negligence due care standard is set at an economically efficient level..$^{18}$ If injurers take the "efficient" amount of care to avoid accidents the total social cost (care costs plus expected accident costs) is lower than at any other level of care they could take. ${ }^{19}$ Since, by assumption, the negligence due care standard is set at an economically efficient level, an injurer that takes the socially optimal level of care (the efficient level) will not be held liable for any accidents; under the legal standard the injurer is not negligent and the cost of any injury will be borne by the injured party. ${ }^{20}$ The fifth assumption is that potential injurers are rational utility or profit

16 See Shavell, supra note 5, at 470.

17 See id.

18 A discussion of the reasonableness of this assumption in economic analysis is beyond the scope of this Comment. For such a discussion see Cooter \& Kornhauser, Can Litigation Improve the Law Without the Help of Judges, 9 J. LEGAL STUD. 139 (1980); Cooter, Kornhauser \& Lane, Liability Rules, Limited Information and the Role of Precedent, 10 BELL J. EcoN. 366, 369-70 (1979). For evolutionary approaches, see Goodman, An Economic Theory of the Evolution of the Common Law, 7 J. LEGAL STUD. 393 (1978); Landes \& Posner, Adjudication as a Private Good, 8 J. LEgal STUD. 235 (1979); Priest, The Common Law Process and the Selection of Efficient Rules, 6 J. Legal STud. 65 (1977); Rubin, "Why is the Common Law Efficient?" 6 J. Legal Stud. 51 (1977); Terrebonne, A Strictly Evolutionary Model of Common Law, 10 J. Legal STUD. 397 (1981). But see Cooter \& Kornhauser, supra, criticizing the evolutionary approach.

10 If a tortfeasor takes less than due care (the "efficient" amount of care, see supra note 18 and accompanying text), then although care costs will be lower, expected accident costs will increase more than care costs will decrease and thus total social cost will be greater than at an efficient negligence due care standard. Conversely, if a tortfeasor takes more than due care, although expected accident costs will be lower, care costs will increase more than expected accident costs will decrease and thus total social cost again is greater than at an efficient negligence due care standard.

${ }^{20}$ An example is illustrative. Table 1 contains a hypothetical example of an accident meeting assumptions 1-3. The data in this table, and successive tables, see infra notes 46,62 , are hypothetical and were chosen to illustrate the assumptions and analysis of the Comment. The examples do not, of course, provide a proof of the analysis. For such a proof, see the Technical Appendix.

Suppose that a chemical company has the option of installing five different types of air filters, where each type of filter corresponds to a different level of care. 
maximizers. ${ }^{21}$

To sum up, the Comment assumes: (1) risk neutrality; (2) increasing total and marginal care costs; (3) decreasing total and marginal expected accident costs; (4) a person is legally negligent if she takes less than the efficient amount of care; and (5) rational utility or profit maximization.

\section{Negligence Rule}

The traditional economic analysis of the passive victim case reveals that injurers will always take the efficient level of care and will never be negligent. ${ }^{22}$ That does not mean that there will be no accidents, but only that an efficient number of accidents will occur and that an efficient amount will be spent on avoiding them. ${ }^{23}$

The reasoning for that conclusion is straightforward. Under a negligence rule, if the injurer takes "due care" she is not negligent and will

TABLE 1

Level of

Care

(filter type)

$\begin{array}{rr} & \$ \\ 1 & 5 \\ 2 & 8 \\ 3 & 12 \\ 4 & 17 \\ 5 & 23\end{array}$

EXPECTED ACcIDENT Costs

$\begin{array}{cc}\text { Probability } & \begin{array}{c}\text { Damage } \\ \$\end{array} \\ .023 & 1000 \\ .017 & 1000 \\ .012 & 1000 \\ .008 & 1000 \\ .005 & 1000\end{array}$

Total

$\begin{array}{cc}\text { P X D } & \text { Costs } \\ \$ & \$ \\ 23 & 28 \\ 17 & 25 \\ 12 & 24 \\ 8 & 25 \\ 5 & 28\end{array}$

A thin, single-ply filter is inexpensive to make and install (type 1 filter care costs equal \$5), while a thick, multi-ply filter is expensive to manufacture and install (type 5 filter care costs equal \$23) (assumption two). Note also that the marginal cost of installing the next safest filter is $\$ 3(\$ 8-\$ 5)$ if the company is deciding between type 1 and 2 filters, while the marginal cost of the next safest filter is $\$ 6(\$ 23-\$ 17)$ if the company is deciding between type 4 and 5 filters (assumption two). Moreover, observe that the thicker the filter, the less likely it is to fail and give chemical workers $\$ 1000$ worth of respiratory damage (expected accident costs for type 1 filter equal $\$ 23$ and for type 2 filter equal \$5) (assumption three). Also note that the marginal reduction in expected accident costs of installing the next safest filter is $\$ 5(\$ 17-\$ 12)$ if the company is deciding between types 2 and 3 filters, while the marginal cost of the next safest filter is $\$ 3(\$ 8-\$ 5)$ if the chemical company is deciding between type 4 and 5 filters (assumption three). Finally, observe that it would be efficient for the chemical company to install type 3 filters because the sum of care costs and expected accident costs are lower (\$24) than for any other level of care.

"1 A person is rational if she always attempts to maximize her present discounted value. In the case of corporate injurers, the fifth assumption implies there is no disparity of interests between those who control the corporation (management) and those who own it (shareholders). A good discussion of that subject, with citations to much of the literature, is found in F.M. Scherer, INDUSTrRIAL MARKET STRUCTURE AND EcoNOMic Performance 32-37 (2d ed. 1980).

22 See sources cited supra note 5 .

${ }^{23}$ That is, total social costs will be minimized. See supra note 20. 
pay only care costs. The injurer will take no more than due care because to do so would needlessly increase her costs. She will not take less care since she would then be liable and have to pay accident costs (damages) as well as whatever care costs she had already paid. ${ }^{24}$ It is important to highlight two aspects of this analysis. First, notice that by taking at least due care, the injurer faces only care costs, while by taking less care, the injurer pays those costs plus an expected damage liability. Second, if she takes less than due care, she must pay both current care costs and future expected damage costs.

\section{Strict Liability Rule}

As was found under a negligence regime, the traditional economic analysis of the passive victim case reveals that injurers will always choose to take the efficient level of care under a strict liability rule. An injurer under a strict liability rule is liable for the victim's injuries, regardless of the care she takes. The injurer, therefore, will choose the level of care that minimizes the sum of care costs and expected accident costs. By definition, the sum is minimized at the efficient due care level. ${ }^{25}$

Two comparisons with the negligence rule should be noted. First, unlike under the negligence standard, there is no sudden jump in the amount of costs the injurer pays if she takes slightly less care than the efficient or due care level of care. That is so because the injurer is liable for the victim's injury under strict liability regardless of the amount of care she takes, while she is liable for damages under the negligence rule only if she takes less than due care. Second, as under the negligence rule, the injurer faces total costs that are comprised of current care costs and future expected damage costs. That is, the injurer's costs are the total social costs; since due care minimizes social costs, the injurer takes due care. From an efficiency perspective the negligence and strict liability rules result in injurers taking identical

24 In the example, supra note 20 , if the chemical company installed type 3, 4, or 5 filters it would be nonnegligent and face care costs of $\$ 12, \$ 17$, or $\$ 23$. Clearly, of the three alternatives, it would pick type 3 , the due care standard. If the company decided to install type 1 or 2 filters, it would face care costs of $\$ 8$ or $\$ 5$ and expected damage costs of $\$ 17$ or $\$ 23$. Thus, the company would face total costs of $\$ 25$ or $\$ 28$. Between those two alternatives, the firm would pick type 2 filters, because $\$ 25$ is less than $\$ 28$. But will the company prefer installing type 2 filters to type 3 filters? Clearly not, because its total liabilities equal $\$ 25$ if it installs type 2 and $\$ 8$ if it installs type 3 filters.

${ }^{23}$ See supra note 20 . For filters $1,2,3,4$, and 5, the injurer faces care costs and expected damage costs totalling $\$ 28, \$ 25$, and $\$ 28$. The minimum of these costs occur with filter 3-the efficient level of care. 
amounts of care to avoid accidents. ${ }^{26}$

\section{B. Economic Analysis of Potentially Insolvent or Absent Injurers}

Assuming that injurers have some expected likelihood of disappearance, they will not always take the efficient level of care under either a negligence or strict liability rule. This Comment will show, however, that the negligence liability rule is more efficient than the strict liability rule because the former better ensures that the injurer will take the efficient amount of care. Specifically, under a negligence rule, injurers will take due care only if their likelihood of insolvency or absence is less than a certain critical likelihood of insolvency or absence. If the injurer's likelihood of insolvency or absence is greater than the critical level, then the injurer will take much less than due care. ${ }^{27}$ In contrast, under a strict liability rule, an injurer will always take less than efficient amounts of care as long as her expected likelihood of insolvency or absence is greater than zero. Finally, an injurer takes the same amount of care under a negligence rule as under a strict liability rule if the injurer's likelihood of insolvency is greater than the critical likelihood of insolvency. Importantly, in interpreting these conclusions it should be recalled that they refer only to the relative efficiency of the rules with respect to the problem of the potentially disappearing injurer.

\section{Assumptions}

The analysis employs the same assumptions as before and adds one additional assumption. We assume that injurers have information about the likelihood of their disappearance and make judgments about how much care to take after considering those likelihoods. There are three reasons for thinking that assumption is reasonable. First, an injurer, in a time of financial crisis, may implicitly discount future liabilities while attempting to solve current financial woes. For example, if a

28 The difference between the two rules is, of course, who bears the cost of those accidents it is not worth preventing, i.e., those that occur even with injurers taking efficient, due care. Under a negligence regime, the victim bears the accident costs, while under strict liability the injurer does.

27 With likelihoods of insolvency or absence greater than the "critical" likelihood, injurers take less than due care; with likelihoods less than the critical level, injurers will take due care. The critical level is a function of the "technology" of an accident: the care costs and expected accident costs at every level of injurer care. Thus, the magnitude of an injurer's critical likelihood varies with the type of accidents that injurer may cause. See infra note 32 . 
creditor is demanding that the injurer pay back an old debt and the injurer has little cash on hand, the injurer may cut back on the level of care she takes in order to reduce her costs and raise the cash to repay the debt. As an obvious example, a firm facing bankruptcy will not invest in worker safety equipment to avoid tort claims in future years. Therefore, potential injurers implicitly discount future liabilities and take less care whenever they are in financial difficulties. ${ }^{28}$

Second, a firm's or individual's likelihood of bankruptcy is frequently evaluated by lenders and thus an injurer will have information about her likelihood of bankruptcy. Lenders make judgments about the riskiness of a loan to a firm or individual and charge a higher borrowing rate, the higher the firm's or individual's likelihood of insolvency. For example, rating agencies scrutinize a company's financial statements and assess its financial strengths before assigning a rating to the company's debt. ${ }^{29}$ Given that an injurer can estimate her likelihood of insolvency, it would be rational for the injurer to use that information in deciding how much care to take because the injurer may increase the present discounted value of her future profit stream by taking less care and counting on a certain probability of disappearing.

Third, if an injurer could reduce costs by taking less care now because she may be insolvent or able to take advantage of procedural rules to discourage a lawsuit, it would be rational for an injurer to learn about her future likelihood of insolvency or absence. A firm or individual could do this in a variety of ways, including hiring lawyers and consulting services. ${ }^{30}$

28 See supra note 21.

29 See, e.g., Moody's OTC Industrial Manual v-vi (1983).

so Before turning to the anlaysis of the negligence and strict liability rule, it is important to note that it is also assumed that the negligence standard of care set by the court is not related to individuals' and firms' likelihoods of insolvency or absence. This qualification to assumption three is warranted for three reasons. First, the explanations of how courts learn of the efficient levels of care do not explain how the court would learn about a firm's or individuals' likelihood of insolvency or absence. For example, according to one explanation, courts set the due care standard from information provided by witnesses about the technology of accidents, not the financial position of the firm, see, e.g., Cooter \& Kornhauser, supra note 18. Moreover, in the single defendant case, courts only hear testimony from solvent defendants, who the courts (probably) assume had a zero likelihood of insolvency or absence at the time of the accident. See infra note 33 and accompanying text. Second, there is no evidence that courts consciously adjust the standard of care to reflect injurer's likelihoods of insolvency or absence. Third, it is not at all clear what a court would or should do if it learns what the injurer's likelihood of insolvency or absence was at the time of the accident. Increase the standard of care? Decrease it? Our analysis, in fact, shows that it would be inefficient for a court to adjust the due care standard to account for injurers' likelihood of insolvency or absence. See infra note 33 and accompanying text. 


\section{Negligence Rule}

An injurer will not necessarily take the efficient level of care when, as assumed, the injurer bases her decisions as to the amount of care to take on, among other things, her likelihood of disappearance. If that likelihood exceeds some critical level, the injurer will take an inefficiently low level of care and thus cause an inefficiently large number of accidents. At likelihoods of insolvency less than that critical level, the injurer will take due care.

In deciding how much care to take, the injurer considers the care costs she must pay now and the expected accident costs that she will have to pay in the future if she is found liable. The conclusion that an injurer's care is discontinuous-that is, the injurer takes reasonable care until the probability of her insolvency or absence rises to a critical level beyond which she will take inefficiently low levels of care-is a result of the discontinuity in the expected costs that an injurer faces under a negligence regime.

To see this conclusion clearly, it is useful to consider an injurer with differing likelihoods of insolvency or absence. If the injurer knows she will become insolvent or be absent from trial (her likelihood of insolvency, $\alpha$, equals one) then the injurer knows she will never have to pay any accident costs, since she will have disappeared. She must pay only current care costs. In this extreme case, then, the injurer would take no care since that is cheaper than taking some care and she will not have to pay for any of the accidents that result. On the other hand, if the injurer knows she will not disappear ( $\alpha$ equals zero) the injurer, as the earlier analysis showed, ${ }^{31}$ will take the efficient level of care.

For any $\alpha$ between zero and one the injurer makes the following calculation: should I take due care and pay only care costs, or should I take a lower level of care and pay less in care costs but also face the possibility of future damage liabilities discounted by the likelihood that I will disappear.

Note that if $\alpha$ were small and the injurer took slightly less than due care, the injurer would pay current care costs plus future expected accident liabilities discounted by a very small amount, i.e., $\alpha$ is almost zero, so the odds of the injurer disappearing are so small that the injurer pays almost all the expected accident costs. Total costs would be greater than those the injurer would pay if she took due care (was not negligent) and paid only care costs. At some critical $\alpha\left(\alpha_{c}\right)$, however, $\alpha$ would be large enough so that the expected future damages liability

s1 See supra note 23 and accompanying text. 
would be discounted enough that the cost of due care would be greater than the sum of care costs and discounted expected accident costs. Beyond that critical $\alpha_{c}$, the injurer, therefore, would take significantly less care. $^{32}$

That conclusion may be conceptualized as follows. At levels of care greater than or equal to due care, the injurer pays only care costs. At lower levels of care the expected accident costs "kick in," and the injurer must pay for them, too. Once those costs "kick in," it takes a large amount of discounting, that is, the critical likelihood of insolvency or absence must be great, in order to lower the expected accident costs enough to make it worthwhile for the injurer to take less than due care.

The analysis not only shows that a negligence liability rule may not be efficient, but also provides a justification for awarding punitive damages when injurers are grossly negligent. ${ }^{3 s}$ Earlier it was pointed out that even if a court knew what a defendant's likelihood of insolvency was at the time of the injury, it was not at all clear how a court might use the information to determine an injurer's liability. If the court simply raised the due care standard when it knew that a defendant's $\alpha$ was greater than zero, then the court might encourage an inefficient level of care. If the defendant's $\alpha$ were greater than zero but less than $\alpha_{c}$ and the court imposed a higher level of care than the efficient level, the injurer would be forced to take an inefficiently high level of

32 See supra note 20 . Recall that if filter 3 were installed, the chemical company faced $\$ 12$ of care costs and no expected future liabilities. This was the level of care the company would choose because at any other level of care, it would face greater expected total costs. Suppose, however, the company had an $\alpha=.1$. If it installs filter 3 it faces costs of $\$ 12.00$, for filter 2, costs totalling $\$ 23.30(\$ 8+(.017)(1000)(1-.1))$ and for filter 1 , costs totalling $\$ 25.70(5+(0.23)(1000(1-.1))$. Obviously, it would opt to install filter 3. Suppose, however, that the company had an $\alpha=.7$. If it installs filter 3 it still faces costs of $\$ 12$. At the higher likelihood of disappearance, however, the expected future liabilities are greatly discounted. If filter 2 is installed, the company faces costs of $\$ 13.10(\$ 8+(0.17)(1000)(1-.7))$ and if filter 1 is installed, the company faces costs of $\$ 11.90(5+(0.23)(1000)(1-.7))$. Therefore, it will be cheaper for the company to install filter 1 - not the efficient level of care.

To see that the company's level of care drops precipitously at some critical $\alpha$, suppose that the company's $\alpha=.68$-only two one-hundreths less than before. Now it faces costs of $\$ 12$ for filter 3 , and $\$ 13.44(8+(0.17)(1000)(1-.68))$ for filter 1 . At $\alpha$ $=.68$, the company will pick filter 3 , while at $\alpha=.7$, the company will pick filter 1 . Observe that the critical value of $\alpha$ may be calculated from the example ( $\$ 12=5+$ $(1000)(.023)(1-. \alpha))$ and equals approximately .696 .

The example shows that if the likelihood of insolvency or absence is less than the critical likelihood, then the due care standard is met (filter 3), while if the likelihood of insolvency is just greater than the standard, the amount of care the injurer picks is substantially less than the standard (filter 1 ). The example also reveals that the critical likelihood of insolvency or absence is a function of the technology of the accident, i.e., the care and expected accident cost functions.

33 Restatement (Second) of Torts § 908 (1979); W. Prosser, supra note 10 , at 9-14. 
care.

The court could, on the other hand, raise the victim's damages when the injurer's $\alpha$ is greater than $\alpha_{\mathrm{c}}$. While the court certainly could not directly observe the injurer's $\alpha$ and $\alpha_{\mathrm{c}}$, it could infer that if the injurer took very little care it was because the injurer's risk of insolvency or absence was greater than the critical risk of insolvency or absence. In such instances, the court should award punitive damages to the victim. The threat of punitive damages where the injurer's $\alpha$ is greater than $\alpha_{c}$ might deter an injurer with a high risk of insolvency from taking less than due care. ${ }^{34}$

\section{Strict Liability Rule}

Under a strict liability rule, an injurer with a likelihood of disappearance greater than zero always takes less than the efficient amount of care. Moreover, as the injurer's likelihood of insolvency rises, the injurer takes less and less care. There is no precipitous drop in the injurer's level of care at some critical likelihood of insolvency.

The analysis is straightforward. The injurer is always liable for the victim's injuries. Therefore, in deciding how much care to take, the injurer evaluates the sum of care costs and expected accident costs discounted by the likelihood that she will be insolvent or absent, for every level of care. If $\alpha$ equals zero, she will take the efficient amount of care, as above. ${ }^{35}$ If $\alpha$ equals one, the injurer will take no care since she will pay zero care costs and zero expected liabilities because she is certain she will disappear. Finally, the injurer will take less and less care as $\alpha$ increases between zero and one, because the injurer's expected total costs do not suddenly rise at some level of care, as under the negligence rule. $^{36}$

\section{Comparison of Negligence and Strict Liability Rules}

A comparison of the negligence and strict liability rules in light of

s4 See supra note 20. Where $\alpha=.7$ and $\alpha_{c}=.696$, the injurer chose to install filter 1 at an expected total cost of $\$ 11.90$ instead of following the standard level of care at a cost of $\$ 12$. A court could encourage the injurer to take the standard level of care if the injurer could have expected to face punitive damages of $\$ 20$, (i.e., filter 1 total costs of $\$ 12.04(5+.023(1000+20)(1-.7))$ versus $\$ 12$ for filter 3$)$.

ss Her likelihood of disappearance is zero, so the traditional analysis is applicable. See supra notes 22-24 and accompanying text.

so See supra note 20. If $\alpha$ equals 0 , then the company installs filter 3 at cost $\$ 24$ $(12+(0.12)(1000))$. If, however, $\alpha$ equals .4, the company will install filter 2 at a lower total cost of $\$ 18.20(8+(.017)(1000)(1-.4))$ and if $\alpha$ equals .7 , the company will install filter 1 at an even lower total cost of $\$ 11.90(5+(0.23)(1000)(1-.7))$. 
an injurer's risk of disappearance reveals that for any risk of insolvency or absence, an injurer will take at least the same, and sometimes more care under the negligence rule than under the strict liability rule. If the injurer's likelihood of disappearance is less than the critical likelihood, the injurer takes an efficient level of care under the negligence rule, and takes an inefficiently low level of care under a strict liability rule. The negligence rule is thus more efficient than the strict liability rule in those cases. If the injurer's likelihood of insolvency is greater than the critical likelihood, the injurer takes the same inefficiently low level of care under either rule. The two rules are equally inefficient in those cases. Overall, then, the negligence rule promotes a more efficient level of care. ${ }^{37}$

\section{Multiple Injurer Case}

Imagine that all accidents involve two injurers and one victim. Also suppose that the victims are passive. Examples of accidents fitting this description include two air polluters whose pollution gives a victim emphysema or two neighbors who share a common wall and must maintain it to keep the wall from collapsing on a pedestrian. ${ }^{38}$ Section A of this part briefly describes the traditional economic analysis of how much care joint injurers will take to avoid accidents and how many accidents are likely to occur under a negligence rule. The section then shows how the results differ if the analysis takes into account injurers' likelihoods of disappearance and analyzes the effects of the recovery and simple rules. Section B analyzes the multiple injury case under a strict liability rule and follows the same organization as section A.

\section{A. Negligence Rule}

\section{Traditional Economic Analysis}

\section{a. Assumptions}

Landes and Posner, in a recent article, ${ }^{39}$ analyze a variety of situations where more than one actor contributes to a victim's injury. They identify a number of different types of joint torts including the "simultaneous joint care" 10 case. A joint tort is "simultaneous" if the tortious acts occur at the same time or there is only one tortious act with uncer-

37 The reader is reminded that the relative efficiency of the negligence rule is limited to its effect in dealing with the problem of the disappearing defendant.

ss See Landes \& Posner, supra note 5, at 518.

39 Landes \& Posner, supra note 5.

to Id. at 517-18. 
tainty as to which of two injurers is responsible. A joint tort is a "joint care" case if optimal accident avoidance requires both parties to take care. ${ }^{41}$ In the example of the two polluters, the joint tort is simultaneous because the pollution from both polluters harms the victim. It requires joint care to avoid because, we shall assume, the sum of care and expected accident costs is lower if both polluters take some care than if only one does. Thus, it is cheaper for each of two equal polluters to reduce their pollution by $50 \%$ than for one of them to reduce her pollution by $100 \%$. That is so because we assume that an injurer's marginal cost of pollution reduction increases with the level of care she takes to reduce pollution.

Landes and Posner also make the assumptions that were used in the single injurer case and further assume that the costs of the joint tortfeasors voluntarily negotiating levels of care are prohibitive. ${ }^{42}$ That assumption means that the injurers will not contract with each other to control each other's decision to take care. This Comment will make the same assumptions.

\section{b. Analysis}

Landes and Posner show that if courts set the negligence standard at the efficent level of care, joint tortfeasors will take that level of care. ${ }^{13}$ They explain that as follows.

Joint tortfeasors $A$ and $B$ face a more complicated set of expected accident costs than in the single injurer case. If $A$ takes due care then $A$ pays only care costs, whether or not $B$ takes due care. If $A$ takes less than due care and $B$ takes due care, $A$ pays care costs at her level of care and is liable for all of the victim's injuries. Finally, if $A$ takes less than due care and $B$ takes less than due care, then $A$ and $B$ share the victim's damages, plus pay for whatever care they did take. $B$, of course, is subject to the same rules.

To show that $A$ and $B$ will take due care, Landes and Posner show: (i) if $B$ takes due care then $A$ will as well; and (ii) if $B$ does not, $A$ will still prefer to take due care. If $B$ takes due care, then $A$ pays either the cost of due care or care costs at a lower level of care plus all of the victim's expected accident costs. Because due care is the efficient level of care, $A$ 's due care costs must be less than the sum of $A$ 's care and expected accident costs at a level of care less than due care. ${ }^{44} A$ will

\footnotetext{
11 Id. at 518.

42 Id. at 521.

43 Id. at $522-26$.

14 $A$ will not be negligent and so will not pay any accident costs.
} 
thus follow the due care standard. Suppose, however, for whatever reason, $A$ thinks that $B$ will take less than due care. If $A$ also takes less than due care, she pays lower care costs, but also pays a share of the expected accident costs. What will $A$ do?" $A$ will still have an incentive to take due care. The proof is by contradiction. If $A$ and $B$ both took less than due care, that would imply that the sum of the care costs and the expected accident costs at those levels of care were less than the sum of those costs at due care standards. ${ }^{45}$ But that, by definition, is not possible because the due care standards were set at a level that minimizes the sum of care and expected accident costs. ${ }^{48}$ welfare.

45 Assuming, see supra note 21 , that $A$ and $B$ act rationally to maximize their

${ }^{16}$ An example may help make the proof clearer. Suppose that the two polluters, $A$ and $B$, choose levels of care $x$ and $y$, respectively, where $x$ and $y$ equal 1 through 5 . Table 2 shows the care costs for every level of care for $A$ and $B$.

\section{TABLE 2}

\section{CARe Costs $(\$)$}

Level of Care
$x, y$
1
2
3
4
5

A

$B$

$\begin{array}{rr}1 & 1 \\ 4 & 8 \\ 9 & 27 \\ 16 & 64 \\ 25 & 125\end{array}$

$$
\text { (Note: } A=\mathrm{x}^{2} ; B=\mathrm{y}^{3} \text { ) }
$$

Table 3 shows the expected accident costs for all of the combinations of care that $A$ and $B$ may take. The table reports the product of the probabilities and damages, i.e., the expected accident costs, for every combination of $x$ and $y$. For example, if $A$ takes 3 units of care and $B$ takes 4 units of care, the expected accident costs equal $\$ 16.60$. The figures in the table conform to our earlier assumptions that at higher levels of care, for either $A$ or $B$, expected accident costs decline, at a declining rate.

TABLE 3

Total Expected Accident Costs

(\$)

\begin{tabular}{ccccccc} 
& \multicolumn{7}{c}{$\begin{array}{c}A \text { 's level } \\
\text { of care, x }\end{array}$} \\
& 1 & 1 & 2 & 3 & 4 & 5 \\
B's level & 200.00 & 100.00 & 66.67 & 50.00 & 40.00 \\
of care, y & 3 & 100.00 & 50.00 & 33.33 & 25.00 & 20.00 \\
& 4 & 66.67 & 33.33 & 22.22 & 16.67 & 13.33 \\
& 5 & 50.00 & 25.00 & 16.67 & 12.50 & 10.00 \\
& 40.00 & 20.00 & 13.33 & 10.00 & 8.00
\end{tabular}

Note: Expected Accident Costs $=\frac{200}{x y}$

Table 4 displays the sum of the care costs and expected accident costs at every level of care. These totals were derived directly from Tables 2 and 3. For example, if $A$ takes 3 units of care and $B$ takes 4 units of care, their care costs are $\$ 9$ and $\$ 64$ and the 
expected accident costs equal $\$ 16.60$. In table 4 , with $A$ at 3 and $B$ at 4 , the total is $\$ 89.60$.

:TABLE 4

Total Social Costs

Sum of Care Costs + Expected Accident Costs

$(\$)$

\begin{tabular}{clrrrrr}
\multicolumn{7}{c}{$\begin{array}{c}\text { A's level } \\
\text { of care, x }\end{array}$} \\
& & 1 & 2 & 3 & 4 & \multicolumn{1}{c}{5} \\
B's level & 1 & 202.00 & 105.00 & 76.67 & 67.00 & 66.00 \\
of care, $y$ & 2 & 109.00 & 62.00 & 50.33 & $49.00^{*}$ & 53.00 \\
& 3 & 94.67 & 64.33 & 58.22 & 59.67 & 65.33 \\
& 4 & 115.00 & 93.00 & 89.67 & 92.50 & 99.00 \\
& 5 & 166.00 & 149.00 & 147.33 & 151.00 & 158.00 \\
& * Minimum cost. & & &
\end{tabular}

Since the due care standards are set equal to the efficient levels of care, the levels of care associated with the lowest total costs are the standards of care for $A$ and $B$. Inspection of table 4 reveals that the cost minimizing levels of care are when $A$ takes 4 units of care and $B$ takes 2 units of care. Therefore, $x$ equals 4 and $y$ equals 2 are the efficient due care levels.

Tables 5 and 6 display the costs that $A$ and $B$ face under a negligence rule. It is assumed, for ease of exposition, that if both $A$ and $B$ are liable each pay one-half of the victim's injuries. This assumption does not affect the analysis. Tables 5 and 6 should be read in the same way as the others. Tables 5 and 6 show that if $A$ takes 4 units of care and $B$ takes 1 unit of care, $A$ faces costs of $\$ 16.00$ (table 5) and $B$ faces costs of $\$ 51.00$ (table 6). Note that at these levels of care $B$ 's costs are much greater than $A$ 's because $B$ is negligent and $A$ is not.

TABLE 5

Total Costs to $A$ Under Negligence Rule

(\$)

\begin{tabular}{crrrrrr} 
& \multicolumn{5}{c}{$\begin{array}{c}\text { A's level } \\
\text { of care, x }\end{array}$} \\
& 1 & 1 & 2 & 3 & 4 & 5 \\
B's level & 2 & 101.00 & 54.00 & 42.33 & $16.00^{*}$ & 25.00 \\
of care, y & 3 & 67.67 & 54.00 & 42.33 & $16.00^{*}$ & 25.00 \\
& 4 & 51.00 & 37.33 & 31.22 & $16.00^{*}$ & 25.00 \\
& 5 & 41.00 & 29.00 & 25.70 & $16.00^{*}$ & 25.00 \\
& & & 24.00 & 22.33 & $16.00^{*}$ & 25.00
\end{tabular}

* Minimum cost.

(Source: Tables 2 and 3).

$A$ nonnegligent if $\mathrm{x}$ equal to or greater than 4

$A$ and $B$ negligent if $x$ less than 4 and $y$ less than 2

$A$ negligent, $B$ nonnegligent

if $x$ less than 4 and

$y$ greater than or equal to 2
Care Costs

Care Costs $+1 / 2$ Expected Accident

Costs

Care Costs + Expected Accident Costs 


\section{Economic Analysis of Potentially Insolvent or Absent Injurers}

The Landes and Posner proof must be extended once one considers that injurers make decisions incorporating an expected likelihood of insolvency or absence. ${ }^{47}$ In general, it can be shown that if $A$ (or $B$ ) has a great enough likelihood of disappearance, then $A$ may exercise less than due care, and then so may $B$. Thus, contrary to Landes and Posner's conclusion, injurers may not take efficient levels of care. The analysis also reveals that given that the negligence rule does not guarantee efficient levels of care, the recovery rule better promotes efficiency than the simple rule.

\section{TABLE 6}

\section{Total Costs to $B$ Under Negligence Rule}

\begin{tabular}{|c|c|c|c|c|c|c|}
\hline \multicolumn{7}{|c|}{$\begin{array}{l}A \text { 's level } \\
\text { of care, } \mathrm{x}\end{array}$} \\
\hline $\begin{array}{l}B \text { 's level } \\
\text { of care, } y\end{array}$ & $\begin{array}{l}1 \\
2 \\
3 \\
4 \\
5\end{array}$ & $\begin{array}{c}1 \\
101.00 \\
8.00^{*} \\
27.00 \\
64.00 \\
125.00\end{array}$ & $\begin{array}{c}2 \\
51.00 \\
8.00^{*} \\
27.00 \\
64.00 \\
125.00\end{array}$ & $\begin{array}{c}3 \\
34.33 \\
8.00^{*} \\
27.00 \\
64.00 \\
125.00\end{array}$ & $\begin{array}{c}4 \\
51.00 \\
8.00^{*} \\
27.00 \\
64.00 \\
125.00\end{array}$ & $\begin{array}{c}5 \\
41.00 \\
8.00^{*} \\
27.00 \\
64.00 \\
125.00\end{array}$ \\
\hline
\end{tabular}

$B$ nonnegligent is y equal to or greater than 2

$B$ and $A$ negligent if $y$ less than 2 and $x$ less than 4

$B$ negligent, and $A$ nonnegligent if $y$ less than 2 and

$x$ greater than or equal to 4

\section{Care Costs}

Care Costs $+1 / 2$ Expected Accident Costs

Care Costs + Expected Accident Costs

The proof of Landes and Posner's proposition is clear from tables 5 and 6. The due care standards are $x$ equals 4 and $y$ equals 2 , and these are the cost minimizing levels of care for both $A$ and $B$. Turn first to table 5 . $A$ is clearly best off taking 4 units of care, as she faces only $\$ 16.00$ worth of costs. From table 6 , it is clear that $B$ is best off taking 2 units of care as she faces only $\$ 8.00$ in costs. Note that if $A$ takes 4 units and $B$ takes 2 units of care, both are as well off as they could be taking any other level of care. Thus, $A$ and $B$ will take 4 and 2 units of care, respectively, the due care standard.

47 Landes and Posner acknowledge that the proof will not work "where one of the injurers will not take care to avoid the accident, with the result that others may not either," Landes \& Posner, supra note 5, at 542, but do not suggest that this may come about from an injurer's expected likelihood of insolvency or absence. 


\section{a. Assumptions}

The analysis starts with the same assumptions as the traditional analysis-the accident fits the simultaneous joint care case ${ }^{48}$ and it is prohibitively expensive for the injurers to negotiate about the levels of care they take-and also assumes that the injurers know and base their decisions on how much care to take on their likelihood of insolvency or absence.

To determine whether the recovery or simple rule is more efficient, we also assume that an injurer has some information about her potential co-tortfeasor's likelihood of disappearance. We need not assume that a potential joint tortfeasor has perfect or average information about her potential co-tortfeasor's likelihood of insolvency or absence, but only that she thinks that her potential co-tortfeasor has a likelihood of insolvency or absence greater than zero.

\section{b. Analysis}

Joint tortfeasors $A$ and $B$ face a more complicated set of possible expected costs. As before, ${ }^{48}$ if $A$ takes due care, she pays only care costs, regardless of how much care $B$ takes. If $A$ takes less than due care and $B$ takes due care, then $A$ pays current care costs at her lower level of care and all of the expected damage liabilities discounted by $A$ 's likelihood of disappearance. If $A$ takes less than due care and $B$ also takes less than due care, then $A$ and $B$ both pay current care costs plus their shares of discounted expected damage liabilities.

Importantly, in this last case, the choice of either the simple or recovery rule affects the amounts by which the expected damage liabilities are calculated. Under the simple rule, $A$ would pay current care costs and her share of the expected future liabilities discounted by her likelihood of insolvency. Under the recovery rule, however, $A$ pays the same care costs and share of expected liabilities, but the expected liabilities are discounted by a lesser amount. That is because if $A$ remains solvent and $B$ becomes insolvent or is absent, $A$ has to pay $B$ 's share of the damages. Thus, under the recovery rule, $A$ 's expected liabilities increase as $B$ 's likelihood of disappearance increases, and are always more than under the simple rule, where $A$ never pays more than her share of damages. ${ }^{\text {.0 }}$

48 See supra note 40.

19 See supra notes 43.46 and accompanying text.

so See note 46. From tables 2, 3, and 5 we know that when $A$ takes 2 units of care and $B$ takes 1 unit of care, both are acting negligently. $A$ faces care costs of $\$ 4$ and her one-half share of the expected liabilities of $\$ 50$, for a total of $\$ 54$. Suppose $\alpha$ equals .4 
Consider the Landes and Posner proof under the simple rule. The proof relied on the proposition that if $B$ takes less than due care, $A$ will still take due care because the sum of $A$ 's care costs and her share of the victim's expected accident costs if $A$ were negligent would be greater than $A$ 's cost of due care. ${ }^{51}$ Our earlier analysis of the single injurer case, however, indicates that if $A$ 's likelihood of insolvency or absence is great enough, $A$ will not take due care. ${ }^{52}$ The proof also relied on the proposition that if $B$ takes due care, $A$ will also, because the sum of $A$ 's care costs and $A$ 's share of the accident costs if $A$ were negligent would be greater than $A$ 's cost of due care. ${ }^{53}$ That proposition is also false because at some likelihood of insolvency or absence $A$ would be better off taking less than due care. ${ }^{54}$ Therefore, under the simple rule, if one of the tortfeasors' risk of disappearance is great enough, a negligence rule does not guarantee that the injurers will take efficient, due care.

\section{c. Recovery and Simple Rules Compared}

The recovery rule is relatively more efficient than the simple rule because, all else equal, an injurer's critical likelihood of insolvency or absence is greater under the recovery rule than under the simple rule. Recall that there is no difference between the two rules if both $A$ and $B$ take due care or if one does and the other does not. ${ }^{.56}$ That is readily apparent because in those two instances, at most one injurer is liable. The choice of rules, under a negligence regime, affects the injurers' behavior only when there is a possibility that both may be liable. That leads us to reconsider the second part of the proof-if $B$ takes less than

and $B$ 's likelihood of insolvency or absence, $\beta$, equals .2. Under the simple rule, $A$ faces care costs of $\$ 4$ plus expected liabilities of $\$ 30((1 / 2)(100)(1-.4))$ or $\$ 34$. Under the recovery rule, $A$ faces the same $\$ 4$ in care costs plus greater future expected liabilities of $\$ 40((100)(1 / 2)(1-.4)+(100)(1 / 2)(.2))$. Also, note that if $\beta$ increases to $.3, A$ 's total costs remain the same under the simple rule, but increase under the recovery rule to $\$ 49(4+(100)(1 / 2)(1-.4+.3)$.

s1 See supra note 46.

52 In the same example at supra note 46, from tables 2,3 , and 5 we know that when $A$ takes 3 units of care and $B$ takes 2 units of care, $A$ faces care costs of $\$ 9.00$ plus expected future liabilities of $\$ 33.33$, or $\$ 42.33$. If $A$ follows the standard of 4 units of care, $A$ faces total costs of only $\$ 16$. If, however, $\alpha$ is greater than $.790(9.00+(1$ $\alpha)(33.33)=16.00)$, then $A$ will prefer to be negligent and take less than due care.

ss See supra note 46.

st See supra note 46. From table 5 we know that if $B$ takes 1 unit of care, i.e., less than due care, and $A$ takes 4 units of care, i.e., due care, $A$ faces costs of $\$ 16$. Also, if $A$ takes 3 units of care and has no risk of insolvency, she faces $\$ 42.33$ total costs. $A$ thus takes due care. If, however, $\alpha$ is greater than the critical $\alpha, .790, A$ will take less care than due care.

ss See supra notes 43-54 and accompanying text. 
due care, what will $A$ do?

The answer under the simple rule is that at a likelihood of insolvency or absence less than the critical level, $A$ takes due care, while at likelihoods greater than that level, $A$ takes less care. The answer is the same under the recovery rule. ${ }^{3 B}$ The difference between the rules, however, is that under the recovery rule, all else equal, $A$ 's critical likelihood of insolvency or absence will be higher than it would be under the simple rule. That result stems directly from the conclusion that under the recovery rule $A$ discounts future damages by a lesser amount than under the simple rule because the recovery rule forces $A$ to pay for $B$ 's share of the damages if $B$ goes insolvent. ${ }^{57}$ That conclusion is equivalent to the proposition that for a given amount of discounted future liabilities, $A$ must have a higher likelihood of insolvency under the recovery rule than under the simple rule before deciding to take less than due care. The critical likelihood of insolvency or absence must therefore also be higher under the recovery rule than under the simple rule. $^{.58}$

The recovery rule is thus relatively more efficient than the simple rule. The most efficient rule would be one that always encouraged $A$ to take due care. Neither the recovery nor the simple rule assures that result. One rule is relatively more efficient than another, however, if it increases the probability that $A$ will take due care and, if $A$ takes less than due care, encourages $A$ to take relatively more care. Under the recovery rule, it is more likely that $A$ will take due care because her critical likelihood of insolvency or absence is greater than under the simple rule. Moreover, when $A$ takes less care ( $A$ 's likelihood of insolvency exceeds the critical likelihood) $A$ will take more care under the recovery rule than under the simple rule. That is so because given any likelihood of disappearance, $A$ will have greater expected accident costs under the recovery rule than under the simple rule. ${ }^{59}$

so See supra notes 50-51 and accompanying text.

87 See supra note 9 and accompanying text.

so An example is illustrative. We observed, supra note 46 , that under the simple rule, if $B$ takes 1 unit of care less than the standard of due care, $A$ will take 1 unit less than the standard if A's likelihood of insolvency exceeds the critical level, .790 . Suppose now that the courts follow the recovery rule and that $A$ thinks that $B$ 's likelihood of insolvency is .2. $A$ 's critical likelihood of insolvency increases to $.825(9.00+1 / 2(1-$ $\alpha)(66.67)(1+.2)=16.00)$. Note also that as $B$ 's likelihood of insolvency rises, $A$ 's critical likelihood of insolvency rises. For example, if $B$ 's likelihood of insolvency or absence equals .4 , then $A$ 's critical likelihood of insolvency equals $.850(9.00+1 / 2)(1-$ $\alpha)(66.67)(1+.4)=16.00)$.

so See supra note 46. Suppose $\alpha=.85$ and $\beta=.2$. If $A$ takes 1 unit of care and $B$ takes 1 unit of care, $A$ faces expected accident costs of $\$ 5.00(1 / 2(1-.85)(66.67))$ under the simple rule and $\$ 6.00(1 / 2(1-.85)(66.67)(1+.2))$ under the recovery rule. 


\section{B. Strict Liability Rule}

\section{Traditional Economic Analysis}

Landes and Posner conclude that imposing strict liability in joint tortfeasor accidents is inefficient in the sense that the joint tortfeasors will not choose to take the efficient due care levels of care. ${ }^{60}$ They conclude, therefore, that the negligence rule is superior to the strict liability rule.

The essence of their proof relies on the observation that when one of the injurers takes care to avoid an accident her expected future accident costs decline and her potential joint tortfeasor's expected accident costs decline as well. That follows from the assumption that accident avoidance requires joint care, that is, both injurers' levels of care affect the likelihood of an accident. Each injurer takes an inefficient level of care because in deciding how much care to take, each is only concerned with her costs and will not consider the benefits that her increase in care confers on the other joint tortfeassor. $A$ takes the level of care that minimizes the sum of her care and expected accident costs and $B$ does likewise. But if each took slightly more care, each would be better off because if $A$ takes more care, $B$ 's expected accident costs decline and if $B$ takes more care, $A$ 's expected accident costs decline. But $A$ wouldn't take more care unless she knew $B$ would as well (and vice versa), and as we assume that it is prohibitively costly for $A$ and $B$ to negotiate about what levels of care to take, ${ }^{61} A$ and $B$ will not take the efficient, higher levels of care. ${ }^{62}$

${ }^{60}$ Landes \& Posner, supra note 5, at 542-43.

- See supra note 42 and accompanying text.

62 Assume that care, expected accident and total costs are the same as those displayed in tables 2,3 , and 4, supra note 46 . Under strict liability, the costs that $A$ and $B$ face are displayed below in tables 7 and 8.

TABLE 7

Total Costs to $A$ Under Strict Liability Rule Sum of Care Costs and Expected Accident Costs

(\$)

\begin{tabular}{rlrcccc} 
& & \multicolumn{5}{c}{$\begin{array}{c}\text { A's level } \\
\text { of care, } x\end{array}$} \\
& & 1 & 2 & 3 & 4 & 5 \\
B's level & 1 & 101.00 & 54.00 & 42.33 & 41.00 & 45.00 \\
of care, $y$ & 3 & 51.00 & 29.00 & 25.67 & 28.50 & 35.00 \\
& 4 & 34.33 & 20.67 & 20.11 & 24.34 & 31.67 \\
& 5 & 21.00 & 16.50 & 17.34 & 22.25 & 21.00 \\
& * Minimum cost. & $14.00^{*}$ & 15.67 & 21.00 & 29.00 \\
& (Source: Tables 2 and 3). & & & &
\end{tabular}




\section{Economic Analysis of Potentially Insolvent or Absent Injurers}

Consideration of potentially insolvent or absent defendants does not alter Landes and Posner's conclusion that strict liability is inefficient. In fact, it reveals that the strict liability rule may be even more inefficient than they conclude. Under a strict liability regime, however, the recovery rule is still relatively more efficient than the simple rule.

The strict liability rule is inefficient, according to Landes and Posner, because it leads injurers to take too little care. ${ }^{63}$ If an injurer's likelihood of insolvency or absence is greater than zero, the injurer will take even less care than the inefficient level she would take without consideration of that likelihood. ${ }^{\text {s4 }}$ That follows from our earlier analy-

\section{TABLE 8}

Total Costs to $B$ Under Strict Liability Rule

Sum of Care Costs and Expected Accident Costs

(\$)

\begin{tabular}{|c|c|c|c|c|c|c|}
\hline \multirow[b]{2}{*}{$\begin{array}{l}B \text { 's level } \\
\text { of care, y }\end{array}$} & & \multicolumn{5}{|c|}{$\begin{array}{l}\text { A's level } \\
\text { of care, } x\end{array}$} \\
\hline & $\begin{array}{l}1 \\
2 \\
3 \\
4 \\
5\end{array}$ & $\begin{array}{r}1 \\
101.00 \\
58.00 \\
60.34 \\
89.00 \\
145.00\end{array}$ & $\begin{array}{r}2 \\
51.00 \\
33.00 \\
43.67 \\
76.50 \\
135.00\end{array}$ & $\begin{array}{c}3 \\
34.33 \\
24.67 \\
38.11 \\
72.34 \\
131.67\end{array}$ & $\begin{array}{r}4 \\
26.00 \\
20.50 \\
35.34 \\
70.25 \\
130.00\end{array}$ & $\begin{array}{c}5 \\
21.00 \\
18.00^{*} \\
33.67 \\
69.00 \\
129.00\end{array}$ \\
\hline
\end{tabular}

Importantly, note that the fact that there is a strict liability rule does not change the efficient levels of care; the cost minimizing levels of care are still where $A$ takes 4 units of care and $B$ takes 2 units of care. The question is, looking at tables 7 and 8 , will $A$ and $B$ take those levels of care? The answer is no. $A$ is best off if she takes 2 units of care and $B$ takes 5 units of care $(\$ 14.00)$. Suppose $A$ then takes 2 units. $B$ is best off if she takes 2 units of care and $A$ takes 5 units of care (\$18.00). Suppose $B$ then takes 2 units. If both take 2, both are worse off than if the other had taken 5 units (for $A$, $\$ 29.00$ versus $\$ 14.00$ and for $B, \$ 33.00$ versus $\$ 18.00$ ). In addition, both are worse off than they would have been had they each taken due care (for $A, \$ 29.00$ versus $\$ 28.50$ and for $B, \$ 33.00$ versus $\$ 20.50$ ). Therefore, acting independently, they each take an inefficiently low level of care.

${ }^{63}$ Landes \& Posner, supra note 5, at 542-43.

ot See supra note 46. $A$ and $B$ may no longer be best off if each takes 2 units and the other takes 5 units. If $A$ 's risk of insolvency or absence equals 71 , for example, $A$ is better off if she takes 1 unit and $B$ takes 5 units $(6.80=1+1 / 2(40)(1-.71))$ than if she takes 2 units and $B$ takes 5 units $(6.90=4+1 / 2(20)(1-.71))$. Similarly, if $B$ 's risk of insolvency is $.31, B$ is better off if she takes 1 unit and $A$ takes 5 units $(14.80=1+$ $1 / 2(40)(1-.31))$, than if she takes 2 units and $A$ takes 5 units $(14.90=8+1 / 2(20)(1-$ $.31)$ ). Therefore, if $A$ and $B$ are each best off if they take 1 unit and the other takes 5, and assuming they cannot negotiate between themselves, then they each may take 1 unit. This, of course, is less efficient than if they each took 2 units of care (total social cost of $\$ 202.00$ if each takes 1 unit versus total social cost of $\$ 62.00$ if each takes 2 
sis of single injurer accidents. ${ }^{65}$ Furthermore, our analysis of the effects of the simple and recovery rules indicates that the recovery rule is more efficient because it forces injurers to discount expected accident costs by a lesser amount than the simple rule, and therefore encourages injurers to take greater care.

\section{CONCLUSION}

Four general conclusions may be drawn from the analysis of potentially insolvent or absent injurers. First, the analysis reveals that in single and multiple injurer accidents a negligence liability rule is more likely to ensure that potential injurers take efficient levels of care to avoid accidents than a strict liability rule. Importantly, it is not argued that, overall, a negligence rule ensures relatively more efficient behavior than a strict liability rule, but simply that a negligence rule better encourages a potential injurer to take efficient levels of care in response to her likelihood of insolvency or absence. Second, the common law rule providing that in multiple injurer acccidents the risk of an injurer's insolvency or absence lies with the other tortfeasors (the recovery rule) encourages potential injurers to take efficient levels of care. ${ }^{68}$ Thus, the economic analysis complements the courts' and commentators' focus on victim compensation ${ }^{67}$ and provides an additional, efficiency-based justification for the rule. Third, economic recessions and procedural rules making it costly for victims to sue injurers increase injurers' likelihoods of insolvency or absence, thereby encouraging them to take less care to avoid accidents and so increasing the number of accidents. Fourth, the analysis shows that negligence and strict liability rules do not operate as efficiently as traditional law and economic analyses presume.

Finally, the analysis in the Comment is useful in providing insight into two recent controversies, one involving the market share liability theory and the other involving the ability of manufacturers to file for reorganization in response to potential tort liabilities.

The advent of the recent market share liability theory ${ }^{68}$ has raised

units).

${ }^{68}$ See supra notes $27-37$ and accompanying text.

See supra notes 3-4.

67 See supra note 9.

os See Sindell v. Eli Lilly Co., 26 Cal. 3d 588, 607 P.2d 924, 163 Cal. Rptr. 132, cert. denied, 449 U.S. 912 (1980) (adopting market share liability in DES case). Other courts have rejected the theory. See In re Related Asbestos Cases, 543 F. Supp. 1152 (N.D. Cal. 1982); Starling v. Seaboard Coast Line R.R., 533 F. Supp. 183 (S.D. Ga. 1982); Mizell v. Eli Lilly Co., 526 F. Supp. 587 (D.S.C. 1981); Ryan v. Eli Lilly Co., 514 F. Supp. 1004 (D.S.C. 1981); Dayton v. Abbott Labs, 386 Mass. 540, 437 N.E.2d 171 (1982). 
the question whether victims or injurers should bear the risk of an insolvent or absent injurer's liabilities. While it is unclear whether the recovery or simple rule will be followed under that new theory, there is evidence that the recovery rule will prevail. In the path breaking case of Sindell $v$. Eli Lilly Co., ${ }^{69}$ the California Supreme Court found a group of manufacturers of diethylstilbestrol (DES)-a drug prescribed in the 1950's to pregnant women to prevent miscarriages-liable for the cancer that the drug caused in those women's daughters. The court held that even though the plaintiff could not identify which drug company manufactured the DES pills that caused her injury, she could recover if she could show that all of the defendants could have manufactured the pills. Each defendant, moreover, was held liable for a share of the plaintiff's injuries proportionate to its market share of the drug at the time the plaintiff purchased the DES. ${ }^{70}$

The majority opinion in Sindell did not explicitly consider whether the recovery or simple rule should be followed if one or some of the drug manufacturers were insolvent by the time of the plaintiff's suit. The court's majority opinion stated, rather ambiguously, "[e]ach defendant will be liable for the proportion of the judgment presented by its share of the market." ${ }^{\text {"71 }}$ An interpretation of this language consistent with the simple rule is that each defendant's share of the damages equals its share of the market. Another interpretation, consistent with the recovery rule, is that each defendant's share of the market determines the proportions of the plaintiff's recovery that the defendants must pay, and that the defendants' liability shares may be greater than their market shares. The dissenting opinion interpreted the majority opinion to mean the latter, ${ }^{72}$ and bitterly criticized such a rule as unfair. The majority's silence in response to that criticism suggests the majority's preference for the recovery rule. ${ }^{73}$ Our analysis of the recovery and simple rules reveals that the recovery rule is more efficient than the simple rule.

6926 Cal. 3d 588, 607 P.2d 924, 163 Cal. Rptr. 132, cert. denied, 449 U.S. 912 (1980). For commentary on the case, see Fisher, Product LiabilityAn Analysis of Market Share Liability, 34 VAND. L. REv. 1623 (1981); Note, Sindell v. Abbott Laboratories: A Market Share Approach to DES Causation, $69 \mathrm{CA}_{\mathrm{A}}$ LIF. L. REv. 1179 (1981); Note, DES and a Proposed Theory of Enterprise Liability, 46 Fordham L. REv. 963 (1978); Note, Market Share Liability: An Answer to the DES Causation Problem, 94 Harv. L. Rev. 668 (1981); Comment, Refining Market Share Liability: Sindell v. Abbott Laboratories, 33 STAN. L. REv. 457 (1981); Note, Proof of Causation in Multiparty Drug Litigation, 56 Tex. L. Rev. 125 (1977).

70 26 Cal. 3d at 613, 607 P.2d at 937, 163 Cal. Rptr. at 145.

7I Id.

72 Id. at 618, 607 P.2d at 940, 163 Cal. Rptr. at 148.

${ }^{3}$ See also Comment, Beyond Enterprise Liability in DES Cases-Sindell, 14 IND. L. REV. 695, 721 (1981) (agreeing with this interpretation). 
Another example of a recent controversy in the law is the recent voluntary filing for reorganization of a large asbestos manufacturer in response to the filing of many tort suits against it for respiratory ailments caused by asbestos. ${ }^{74}$ To the extent that filing for voluntary reorganization"reduces a tortfeasor's liabilities below what they would have been without the aid of the bankruptcy laws, the ability to file for reorganization reduces a potential tortfeasor's critical likelihood of insolvency and therefore reduces the tortfeasor's incentives to take efficient levels of care. If those manufacturers were held strictly liable, then the analysis of single injurer accidents under a strict liability regime indicates that manufacturers' ability to file for reorganization would encourage the manufacturers to take inefficiently low levels of care. Under a negligence regime the manufacturers would take inefficiently low levels of care only if the manufacturers' likelihood of insolvency were higher than the manufacturers' new, lower critical likelihood of insolvency. A priori it is not clear whether this would occur, but the ability to receive reorganizational relief makes it a possibility.

74 See generally Comment, Relief From Tort Liability Through Reorganization, 131 U. PA. L. Rev. (forthcoming 1983). 